\title{
2-octyl-cyanoacrylate glue for fixation of STSG in genitourinary tissue defects due to Fournier gangrene: a preliminary trial
}

\author{
Fournier gangrenine bağlı genitoüriner doku defektlerinde \\ STSG fiksasyonu için 2-oktil-siyanoakrilat doku yapıştırıcının kullanımı: \\ Bir ön çalışma
}

\author{
Nazan SİVRIOĞLU, Saime İRKÖREN, Ender CEYLAN, Ali Murat SONEL, Eray COPÇU
}

\section{BACKGROUND}

In these reported cases, we observed the outcomes of skin take and wound healing using 2-octyl-cyanoacrylate glue, which was used as tissue glue in the reconstruction of complex genital skin loss due to fournier gangrene.

\section{METHODS}

Fifteen patients with Fournier's gangrene were treated in this study. After initial surgical debridement, all defects were repaired using STSG. In this method a thin layer of 2-octylcyanoacrylate was dripped on the recipient site immediately before graft application. All wounds were followed up postoperatively and observed for evidence of graft take, seroma or hematoma formation, drainage, and infection. Patient and physician satisfaction were also determined.

\section{RESULTS}

Grafts were completely accepted in all fifteen patients. None of the patients had wound infection, seroma, hematoma, or other complications.

\section{CONCLUSION}

Use of 2-octyl-cyanoacrylate glue (Glueseal) for STSG fixation in complex genital skin defects after Fournier gangrene may be an acceptable alternative to conventional surgical closure with a good cosmetic outcome. Further studies are needed to confirm our initial success with this approach.

Key Words: Cyanoacrylate; Fournier gangrene; skin graft.
$A M A C ̧$

Fournier gangrenine bağlı kompleks genital doku kayıplarının rekonstrüksiyonda 2-oktil-siyanoakrilat doku yapıştırıcısı kullanarak doku iyileşmesi ve greft tutması ile ilgili klinik sonuçlarımız ve gözlemlerimizi sunmayı amaçladık.

\section{GEREÇ VE YÖNTEM}

$\mathrm{Bu}$ çalı̧̧mada Fornier gangreni olan 15 hasta tedavi edildi. Cerrahi debridmanın ardından oluşan tüm defektler STSG kullanılarak tamir edildi. Greft uygulanmadan önce ince bir tabaka halinde 2-oktil-siyanoakrilat alıcı sahaya damlatıldı. Ameliyat sonrası dönemde tüm yaralar, greft tutmas1, enfeksiyon gelişimi, hemetom, seroma oluşumu ve drenaj açısından gözlemlendi. Aynı zamanda hasta ve doktor memnuniyeti belirlendi.

\section{BULGULAR}

Tüm hastalarda uygulanan greftler tamamen kabul edildi. Hiçbir hastada enfeksiyon, seroma veya diğer ameliyat sonrası komplikasyonlar izlenmedi.

\section{SONUÇ}

Fournier gangreninden sonra oluşan kompleks genital cilt kayıplarında uygulanan STSG'nin fiksasyonu için 2-oktilsiyanoakrilat (Glueseal) doku yapışrıcısının kullanımı iyi kozmetik sonuçları ile birlikte konvansiyonel cerrahi kapama prosedürlerine alternatif olabilir. Bu yöntem, bizim başlangıç başarılarımızın doğrulanması için ileri çalışmalarla desteklenmelidir.

Anahtar Sözcükler: Siyanoakrilat; Fournier gangreni; deri grefti. 
Fournier first described cases of rapidly progressing fulminating genital gangrene in 1883. Fournier's gangrene is a synergistic infection of the genitals and perineum that is produced by a combination of aerobic and anaerobic organisms. Along with broad spectrum antibiotics, treatment comprises aggressive surgical debridement that frequently leads to extensive loss of scrotal skin. The resultant tissue defects often need complex reconstruction including flaps or grafts. ${ }^{[1-3]}$ The aim of the reconstructive procedures after the initial debridement is to attain good coverage of the defects and suitable cosmetic results. Cyanoacrylate tissue glue is an organic polymer that can close simple lacerations in humans and animals efficiently, and acts in a bacteriostatic fashion against Gram-positive microorganisms. ${ }^{[4,5]}$ It results in more reliable wound healing of contaminated lacerations than conventional suture material..$^{[4,6,7]}$ This adhesive has now been used for skin graft fixation in multiple areas.

We conducted this study in order to report the outcomes of graft take and wound healing in this first reported series in which 2-octyl-cyanoacrylate glue (Glueseal) was used as tissue glue in the reconstruc- tion of complex genital skin loss due to fournier gangrene.

\section{MATERIALS AND METHODS}

Between January 2009 and November 2011, fifteen patients with a diagnosis of Fournier's gangrene were admitted to our clinic. These patients were referred to our Division of Plastic and Reconstructive Surgery for reconstruction of defects to the scrotum and/or perineum. All patients underwent antibiotic treatment and emergency surgical debridement performed by urologists or plastic surgeons. Fifteen patients participated in this trial; the patients' ages ranged from 42 to 74 years (mean 52.6 years). Of the patients, 7 had hypertension, 10 had Diabetes (type 2) and 12 were cigarette smokers.

Broad-spectrum antibiotics were prescribed for each patient, and these were changed to specific antibiotics after a specific organism was isolated from the wound culture. Local wound care was performed after debridement, and repeated surgical debridement was performed in the case of residual necrotic skin or soft tissue (Fig. 1a-c). Local wound care was performed
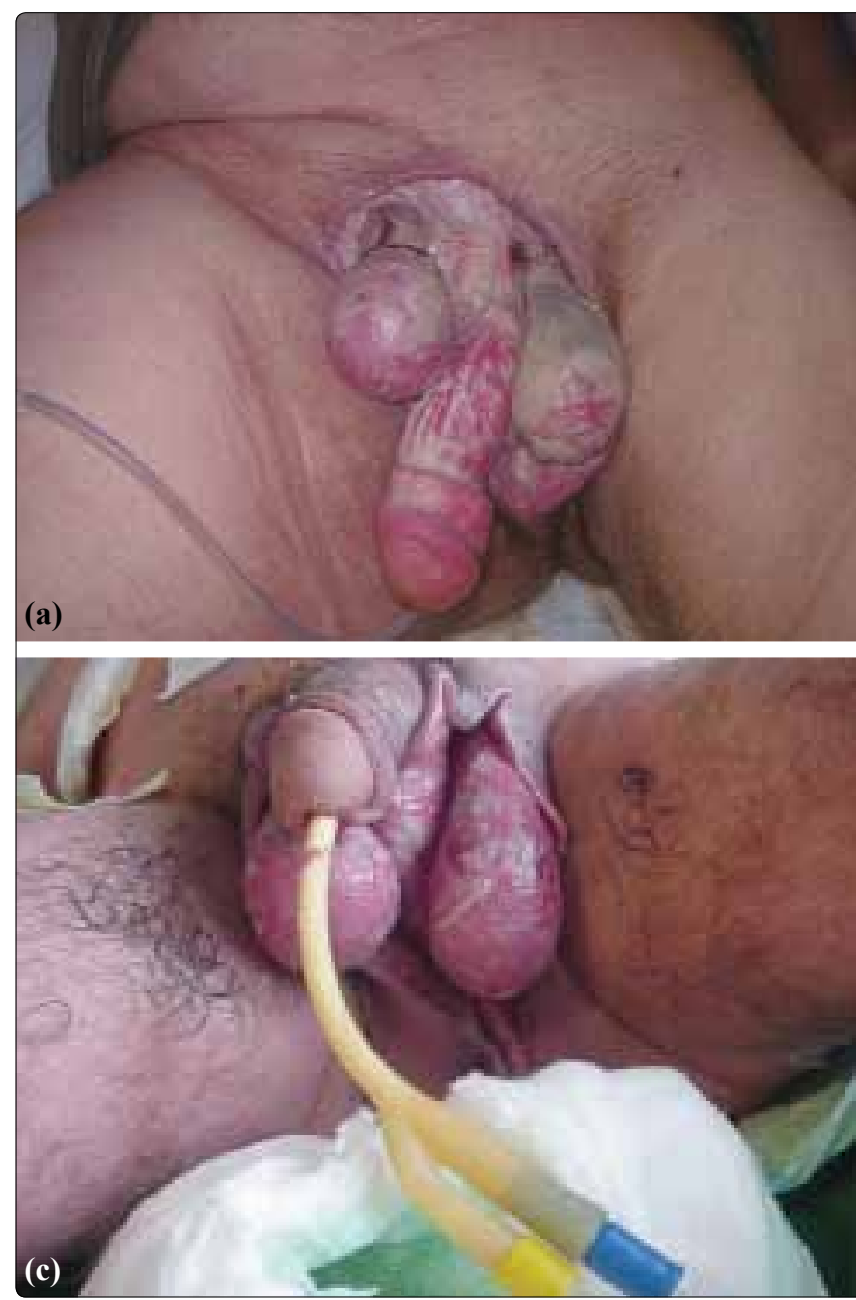

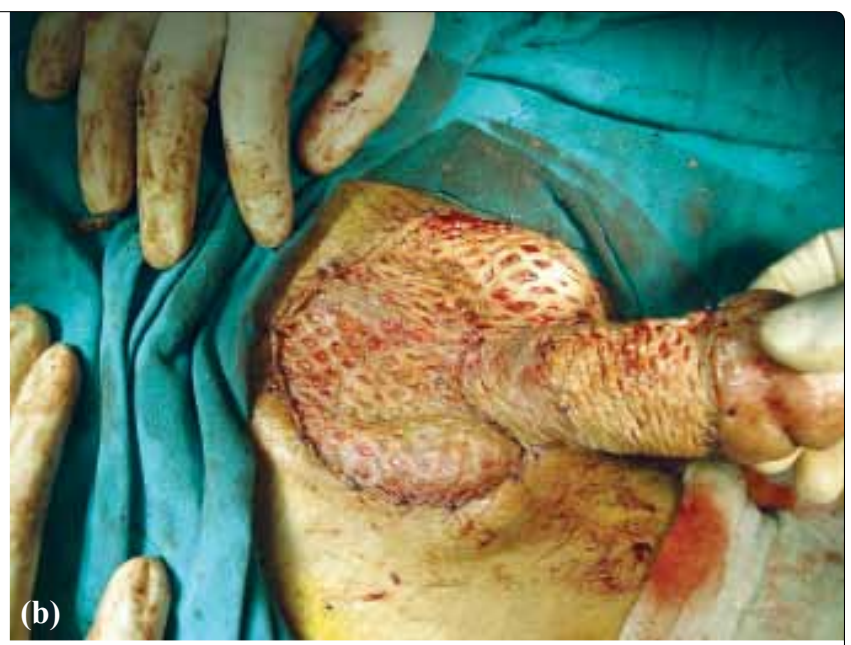

Fig. 1. (a) Preoperative view of 55 year old man with scrotal and penile defect resulting from Fournier's gangrene after debridement (underlying cause was unknown). (b) Patient from Figure 1 with an intraoperative view after applying cyanoacrylate and skin graft. (c) Preoperative view of a diabetic 63 year old man with scrotal defect resulting from Fournier's gangrene debridement (cause was a scrotal abscess).

(Color figures can be viewed in the online issue, which is available at www.tjtes.org). 


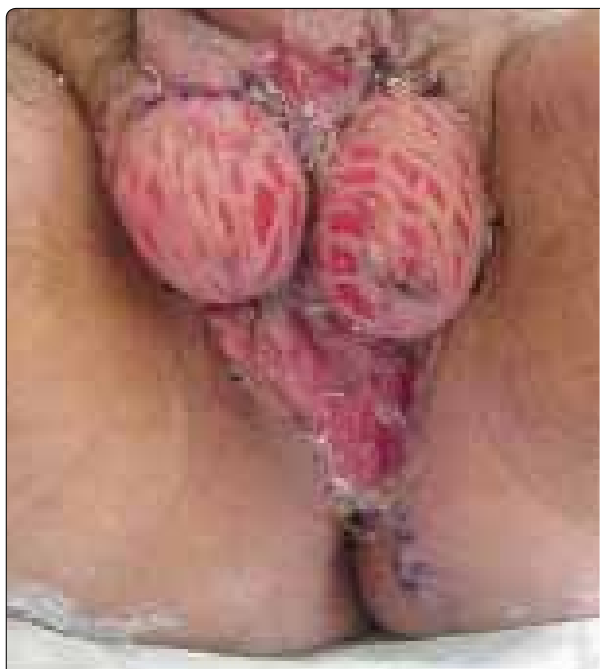

(a)

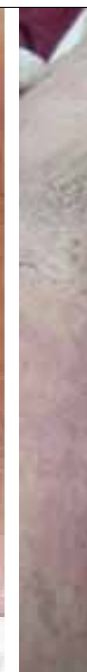

(b)
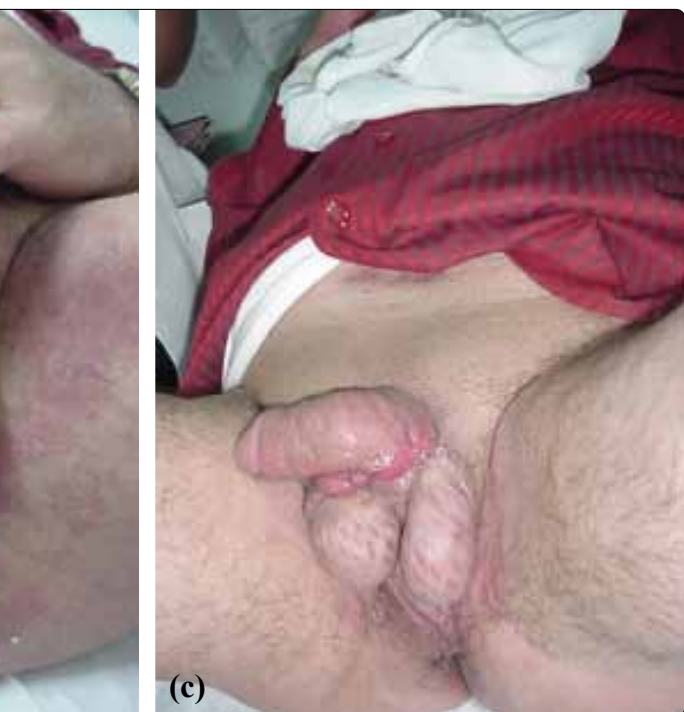

Fig. 2. (a) Early postoperative view of the patient from Figure 3 after removal of xeroform gauze. (b) Postoperative view of the patient from Figure 3 on the 17th day. (c) Postoperative 3 month view of the patient from Figure 3.

(Color figures can be viewed in the online issue, which is available at www.tjtes.org).

using a wet-gauze dressing with saline-diluted iodine in fifteen patients. The wet-gauze dressing was applied and changed two to four times per day. Prior to grafting the testicles and cords were evaluated for tissue viability. The testis and spermatic cord were prepared for grafting by tangentially excising redundant granulation tissue. A thin layer of the cyanoacrylate glue was injected or sprayed evenly on the wound bed before graft placement. Finally, a 2:1 meshed skin (12/1000 in. thickness) was applied on the denuded testicles and cords and was fixed in place. A few interrupted quilting sutures and staples were used as needed to further secure the graft to the underlying tissue. Direct manual pressure was applied over the graft for 1 to 2 minutes to ensure good apposition (Fig. 1b).

Grafts were covered with Xeroform gauze and then with fluff gauze for additional immobilization. The dressings were left intact for 3 to 5 days, and then daily changes were performed with Xeroform gauze until a physician deemed them unnecessary. All grafts were followed up closely for evidence of graft take and the presence or absence of hematoma, seroma, infection, or wound breakdown.

\section{RESULTS}

In all cases, the cyanoacrylate glue allowed time for meticulous graft positioning. The excellent tissue adherence decreased the need for time-consuming quilting sutures. The grafts healed extremely well, with $100 \%$ graft take in all patients (Fig. 2a-c). No patients developed infection, hematoma, or seroma formation. Both the patients and physicians satisfaction were remarkable. The hospital stay varied between $7-12$ days (mean $=9$ days).

\section{DISCUSSION}

Fournier's gangrene mostly occurs in patients with advanced age, diabetes, alcoholism and other preexisting medical problems. These may intensify their operative risk, predominantly for longer or multiple procedures. ${ }^{[1-3]}$ The ideal method of coverage should be technically easy to accomplish and of lower cost. There are few reports in the medical literature in which tissue adhesives are used for skin graft fixation. Craven and Telfer reported good results for full-thickness skin graft fixation with N-butyl-2-cyanoacrylate (NBCA) compared to sutures in patients after Mohs surgery. ${ }^{[8,9]}$ In the literature, and to the best of our knowledge, there are no studies using cyanoacrylate adhesive for split-thickness skin grafts in fournier gangrene.

The proper fixation of skin grafts is important to prevent graft mobilization and, therefore, impaired revascularization and graft survival. ${ }^{[1,3,8]}$

Cyanoacrylates have been studied in various animal models to evaluate their successfulness in the treatment of contaminated surgical incisions, excisional wounds and unclean burn wounds. Also, cyanoacrylates have a very important advantage because of lower infection rates compared to traditional suture techniques in contaminated wound models. The existing studies have shown that cyanoacrylates act like a barrier against microbial penetration and serve as an optimal wound dressing, while providing a moist environment to enhance wound healing. ${ }^{[4]}$ Recent in vitro studies have shown that 2-octylcyanoacrylate is effective as an antimicrobial barrier for the first $72 \mathrm{~h}$ after application. The skin shaped by 2-octylcyanoacrylate is effective against Gram-positive and Gram-negative 
bacteria, together with mobile and non-mobile species, such as $S$. epidermidis, $S$. aureus, Escherichia coli, Pseudomonas aeruginosa and Enterococcus faecium. ${ }^{[4-6,8,10]}$ Suture material can act as a foreign body and trigger an infection during conventional wound closure, while cyanoacrylate tissue adhesives do not donate to foreign bodies that act as a reservoir for microorganisms. Therefore, it offers closure and protection with the advantage of better postoperative wound management and reduces costs. The skin adhesiveness forms a protective layer for the wound assisting a faster epithelization.

We reported for the first time the use of absorbable cyanoacrylate graft sealant in fournier gangrene.

Our impression; in terms of both graft survival and length of hospitalization; is that tissue adhesive is as good as the method using skin staples and sutures for skin graft fixation in patients with fournier gangrene.

There are several potential advantages of cyanoacrylate surgical sealant over other conventional suturing techniques. First, cyanoacrylates were demonstrated to be good sealants even on wet surfaces with bacteriostatic and bactericidal effects in the previous studies. ${ }^{[4-13]}$ Second, since cyanoacrylate closes the wound mechanically, bleeding is reduced and its effect is independent of the patient's hemostatic function. This may be of particular importance for diabetic patients with atherosclerotic or fragile vessels. Third, owing to the capabilities of room temperatures storage and short preparation time, its application is easy and convenient. Fourth, skin staples and sutures, especially in large areas, are painful and time-consuming to remove. Fifth, the use of cyanoacrylate decreases the incidence of hematoma formation so as to achieve a higher graft survival rate. Sixth, the challenges posed by the complex contours of the male genitalia were overcome by the excellent adherence promoted by the cyanoacrylate adhesive. The graft may not be effective when applying it on an uneven or concave wound surface. The use of tissue adhesive overcomes these problems. ${ }^{[4-13]}$

Last, for the directed usage, the cost of cyanoacrylate sealant is lower than most other sealants and conventional suture methods.

In this preliminary study, it was stored at room temperature and was rapidly prepared in the applicator device for quick availability and use by the surgeon. The safety of this material in this study seemed tolerable with no adverse events linked to the use of the agent. Based on this initial data, a larger trial is now in progress to further evaluate safety and effectiveness.
In conclusion, this case demonstrated the potential benefits of cyanoacrylate sealant applied for skin graft fixation to patients with fournier gangrene. Although further studies are required to identify patients who benefit most from its use, it seems to be reasonable to use cyanoacrylate sealant in fournier gangrene where there is a high risk of bleeding, infection and graft lysis complications. A long-term evaluation of this agent will still need to be done to be sure that it harbors no long-term risk to patients.

Conflict-of-interest issues regarding the authorship or article: None declared.

\section{REFERENCES}

1. Maguiña P, Palmieri TL, Greenhalgh DG. Split thickness skin grafting for recreation of the scrotum following Fournier's gangrene. Burns 2003;29:857-62.

2. Ozturk E, Ozguc H, Yilmazlar T. The use of vacuum assisted closure therapy in the management of Fournier's gangrene. Am J Surg 2009;197:660-5.

3. Chen SY, Fu JP, Chen TM, Chen SG. Reconstruction of scrotal and perineal defects in Fournier's gangrene. J Plast Reconstr Aesthet Surg 2011;64:528-34.

4. Losi P, Burchielli S, Spiller D, Finotti V, Kull S, Briganti E, Soldani G. Cyanoacrylate surgical glue as an alternative to suture threads for mesh fixation in hernia repair. J Surg Res 2010;163:e53-8.

5. Ellman PI, Brett Reece T, Maxey TS, Tache-Leon C, Taylor JL, Spinosa DJ, et al. Evaluation of an absorbable cyanoacrylate adhesive as a suture line sealant. J Surg Res 2005; 125:161-7.

6. Costa HJ, Pereira CS, Costa MP, Fabri FS, Lancellotti CL, Dolci JE. Experimental comparative study in rabbits of three different ways of cartilage graft fixation: suture, gelatin-resorcin-formaldehyde and butyl-2-cyanoacrylate. Acta Otolaryngol 2007; 127:947-51.

7. Saba D, Yilmaz M, Yavuz H, Noyan S, Avci B, Ercan A, et al. Sutureless vascular anastomoses by N-butyl-2 cyanoacrylate adhesive: an experimental animal study. Eur Surg Res 2007;39:239-44.

8. Adler N, Nachumovsky S, Meshulam-Derazon S, Ad-El D. Skin graft fixation with cyanoacrylate tissue adhesive in burn patients. Burns 2007;33:803.

9. Sageshima J, Ciancio G, Uchida K, Romano A, Acun Z, Chen L, et al. Absorbable cyanoacrylate surgical sealant in kidney transplantation. Transplant Proc 2011;43:2584-6.

10. Karatepe O, Ozturk A, Koculu S, Cagatay A, Kamali G, Aksoy $\mathrm{M}$. To what extent is cyanoacrylate useful to prevent early wound infections in hernia surgery? Hernia 2008;12:603-7.

11. Taravella MJ, Chang CD. 2-Octyl cyanoacrylate medical adhesive in treatment of a corneal perforation. Cornea 2001;20:220-1.

12. Aksoy M, Turnadere E, Ayalp K, Kayabali M, Ertugrul B, Bilgic L. Cyanoacrylate for wound closure in prosthetic vascular graft surgery to prevent infections through contamination. Surg Today 2006;36:52-6.

13. Hallock GG. Expanded applications for octyl-2-cyanoacrylate as a tissue adhesive. Ann Plast Surg 2001;46:185-9. 